\title{
HOW DID THE POPULATION IN THE COPENHAGEN REGION CHANGE, 1960-2002?
}

\author{
Sven Illeris \\ Roskilde University \\ P.O.Box 260, DK-4000 Roskilde, Denmark \\ e-mail: illeris@ruc.dk
}

\begin{abstract}
Absrtact
The article concentrates first of all on the analysis of spatial differences in the sixty-year development of the population within the concentric zones: city centre, flanking region, old and new suburban circle and dispersed settlements. Indicators, which were subject of a special analysis were age, socio-economic and ethnical structure of the population.
\end{abstract}

Key words: Copenhagen, population, urban growth, gentrification, concentric zones, inner areas, age groups, socio-economic classes, students, excluded persons, immigrants

A simple, popular model of urban growth: As more individuals settle in cities, these grow outwards. The people who move into new, peripheral parts of the city are likely to be younger than people who live in the older, more central parts. Almost everybody is aware that some parts of a growing city are more attractive than other parts, and that those who have most resources are able to get into the best parts, leaving less attractive parts to the rest.

The reason to write this paper is that though in Copenhagen the simple model basically held true for a long period, this is not the case any longer. A number of fascinating new developments have emerged in recent decades. The purpose of the paper is to describe recent changes in the intra-urban distribution of population in the Copenhagen urban region and to discuss possible explanations. In particular, two questions will be analyzed:

- the distribution of the population as a whole, and

- the distribution of different age-, socio-economic, and ethnic groups of the population.

The paper will primarily analyze the distribution of population in concentric belts: the city centre, the surrounding inner areas, the older and newer suburban belts, and the periurban belt including old towns, villages and dispersed settlement. In particular, it will scrutinize the population changes that have taken place in the inner areas belt surrounding the historical city centre. The differences between the population groups living in the various sectors radiating from the centre will be obvious in some of the maps. However, these differences have not changed much in recent decades and will not be discussed in depth. 
In the first sections of the paper, existing theories and methodology will be discussed. The main parts will deal with the changing distribution of the population as a whole, and next with the distribution of the different age-, socio-economic and ethnic groups. On this basis, possible theoretical conclusions will finally be discussed.

\section{RECEIVED THEORY}

In this section, I shall briefly discuss the most important theoretical contributions that focus on the concentric structure of cities, thus leaving apart theories which focus on the different radiating sectors.

Burgess (1925) presented a model of concentric zones, characterized both by buildings and by their inhabitants. Important aspects are the expansion of the city and the succession process in which each concentric zone invades and presses the preceding one outwards. The "best families" occupied the most peripheral zones. The Chicago school of sociologists, to which Burgess belonged, often presented themselves as "human ecologists" and perceived competition between groups for areas and buildings as the driving force of the process.

This model has been heavily critisized, see e.g. Simonsen (1976). For the present paper, the main weakness is that although it is presented as an "ideal" model, it is not clear for what society it is supposed to be valid: For the "modern" American city at Burgess' time of writing, or for cities in all places and periods?

A theory of a purely economic nature was suggested by Alonso's (1960) in which different population groups would reside inside a city where everybody was assumed to work in the city centre. He showed that the relative location of different population groups would form concentric belts depending on their relative land consumption and the value they put on the time used for transport. Assuming that for wealthy groups the highest priority would be given to a high consumption of land for their residences, he could explain that they would tend to live in more peripheral belts than the poorer groups.

This model has a typical neoclassical character, it is static and is based on an "economic man" assumption and other unrealistic assumptions such as the one that only transport between the residence and the city centre counts. It has been heavily critisized, too (Simonsen, 1976), and it has been shown that if some wealthy groups value the time used for transport more than high land consumption, they will prefer central to peripheral belts.

Very different theories have been suggested by Marxists, e.g. Harvey (1989). In a text from the 1970s, he suggests that suburbanisation is actively produced by capital, e.g. through the advertising industry, because it sustains the effective demand for products such as one family houses, household machines and private motor-cars. Furthermore, the capitalist society has created a group of white-collar workers who are imbued with the ideology of competitive and possessive individualism, appropriate for suburban consumption.

It should be added that in another text from 1987 (in the same volume), Harvey mentions that a new and relatively affluent generation has come to dominate whole zones of inner city urban space. This phenomenon, usually called gentrification, has become the object 
of its own theories, summarized by Hamnett (1991). Some authors find the causes on the supply side, in the possibility for capital to obtain increased profits out of well-situated real estate with decaying old structures by renovating these and offering more attractive dwellings to classes that are able to pay higher rents than the traditional working class. Other authors focus on the demand from new, well educated and relatively affluent "service classes" who prefer to live in inner cities, largely in order to satisfy their need for "cultural" consumption. Deplorably, neither of these schools explicitely address Alonso's trade-off between the maximisation of suburban land consumption and transport minimisation (though Hamnett admits that only some of the growing service classes show a preference for inner city living).

Both Alonso's and Harvey's primarily deductive theories and Burgess' model which is more inductive but of dubious general validity see the different socio-economic status of people as a factor causing concentric differentiation of cities. On the other hand, empirical but purely descriptive studies of the internal structure of cities - the so-called social area analyses - from the 1950s and 60s found that socio-economic characteristics of the population showed radiating patterns, while age and family variables were distributed in concentric belts (Pedersen, 1967).

\section{METHODS}

In this brief version of the study, most methodological details have been left out. Suffice it to mention that it is based on public statistics (censuses and registers) from the following years:

- 1960 , before the changes started.

- 1976 which must serve as a proxy for the situation at the first oil crisis that put an end to the period of rapid economic growth and the population growth in the Copenhagen region, and which triggered an increasing rate of unemployment.

- $\quad 1994$, when unemployment peaked, to be succeeded by a new period of economic growth and population growth in the Copenhagen region.

- 1999,2000 or 2002 as the most recent data.

As in most studies of the Copenhagen region in the second half of the 20th century, the study area of this paper will be delimited to include the central local government areas (communes) of the City of Copenhagen and Frederiksberg plus the counties of Copenhagen, Frederiksborg and Roskilde - altogether the area roughly up to 50 kilometres from the city centre and roughly identical with the commuting area of Copenhagen, with a population of 1,815,000 (2002). It is subdivided into 50 communes and the City of Copenhagen further into 20 (from the 1990s only 15) districts. In the tables, these units are aggregated into 7 concentric zones, shown in figure 1.

It should be added that right from the beginning of the expansion in the mid-19th century, a differentiation has prevailed between working class and lower middle class areas to the west and south of the centre - and wealthy areas to the north (both with a few exceptions). 
Figure 1: City of Copenhagen and Frederiksberg

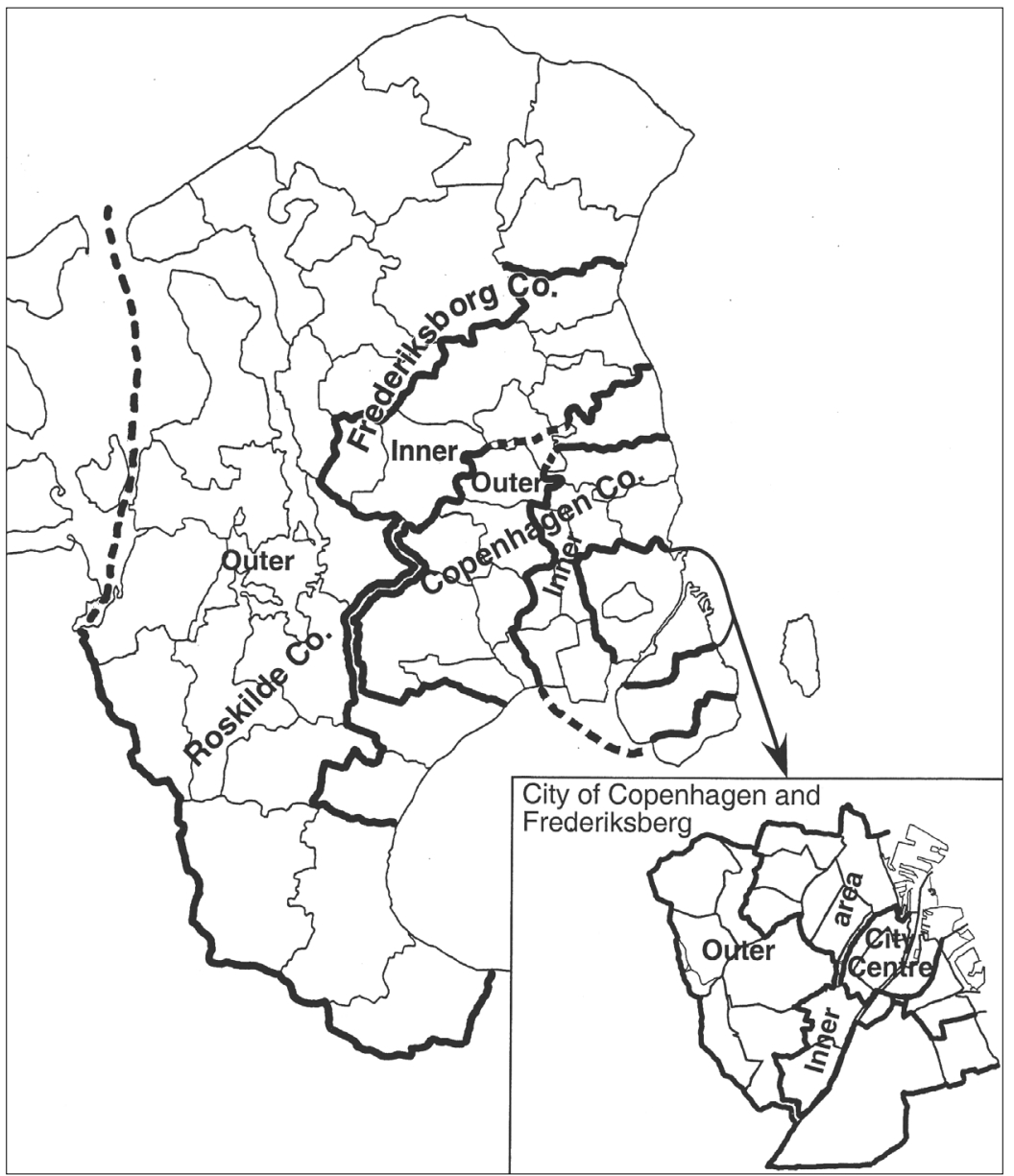

\section{THE OVERALL DISTRIBUTION OF POPULATION I960-2002}

The City of Copenhagen and Frederiksberg reached their population peak in 1950. In the 1960-76 period suburbanisation was rapid. The highest growth rates, up to $15 \%$ annually, were reached in the outer county of Copenhagen and the inner counties of Frederiksborg and Roskilde. At the same time, the central communes were losing population, the inner areas at a rate of $3 \%$ per year corresponding to $40 \%$ over the sub-period. This development was fuelled by the increasing wealth of virtually the whole population, much of which was spent on one-family houses and private motor-cars.

In the 1976-94 sub-period, where the Copenhagen region as a whole had a slightly decreasing population, the redistribution of population became much more modest. Growth rates - now occurring almost exclusively in the counties of Frederiksborg and Roskilde - 
only in a few rural communes exceeded $1 \%$ per year. On the other, hand the population in the central communes gradually stabilized. This was partly due to the development of the different population segments, to be analyzed later. Another part of the explanation was that the building of new ownership housing in the sub- and periurban zones for a number of economic and legal reasons was reduced, thus forcing people to remain in the existing housing stock (Illeris, 1994).

The renewed growth of the region's population since 1994 has been accompanied by an almost complete standstill of the outward movement of the population wave. In 50 of the 64 communes/districts, there has been an annual growth between 0 and $1 \%$ per year, and in the remaining ones the development has been only marginally lower or higher. A hypothesis which may explain this fact could hold the communes responsible: Deterred by the problems which both rapid growth and rapid decline had caused in the preceding decades, they may all have used their considerable powers to keep new house-building on a modest level.

\section{AGE GROUPS}

The first groups to be examined are the age groups of the population. Tables 1-5 show the age structure of the concentric zones over the study period. The following classification into a few age groups has been applied:

- Age group 0-19. Children and adolescents, normally living with their parents. Their number strongly declined after the introduction of the pill in 1966. In the early part of the study period, many young people in the 15-19 bracket had a job. Now the large majority are under education, but many also have part-time jobs or some work as part of their education.

- $\quad$ Age group 20-34, characterized by high migration rates. In 1960 when few persons especially few women - received higher education, and marriage and birth of the first child typically took place in the mid-twenties, the period before long-lasting or permanent settling down typically lasted only to the age of 30 . From the 1970 s, it has often extended to the age of 35 , since many more receive long educations. The students tend to move away from their parents. The first child is typically born when the mother is 30. To retain comparability, the delimitation will be 20-34 all over the study period.

- Age group 35-64. Married couples and singles with or without children, mostly economically active and rarely moving.

- Age group 65 and over. As in all economically advanced societies, this group - mostly of retired persons - is increasing. It should be noticed that in Denmark, retirement migration is a rare phenomenon.

The declining group aged 0-19 all through the study period has been under-represented in the central communes and over-represented in the sub- and periurban counties.

The 35-64 group constitutes a rather stable share of the total population. Up to 1976, the group was over-represented in the central communes and under-represented in the sub- 
and periurban counties; from the 1980s the opposite has been the case with the exception of the city centre where some gentrification takes place. However, the differences from zone to zone have always been relatively modest.

Table 1. Age structure in concentric zones, 1960-1976-1994-2002

\begin{tabular}{|l|r|r|r|r|r|}
\hline Percent & $0-19$ & $20-34$ & $35-64$ & 65 and over & Total \\
\hline City centre & 22.9 & 23.0 & 40.4 & 13.8 & 79,000 \\
\hline Inner areas & 25.7 & 18.2 & 42.2 & 13.9 & 418,000 \\
\hline Outer City of Cop., Fr.berg & 27.8 & 18.6 & 41.6 & 12.0 & 337,000 \\
\hline Inner County of Copenhagen & 34.2 & 23.5 & 35.6 & 6.7 & 401,000 \\
\hline Outer County of Copenhagen & 36.7 & 24.1 & 32.7 & 6.5 & 88,000 \\
\hline Inner Counties of Fr.borg \& Rosk. & 36.4 & 21.6 & 34.4 & 7.6 & 62,000 \\
\hline Outer Counties of Fr.borg \& Rosk. & 34.1 & 19.7 & 35.8 & 10.3 & 221,000 \\
\hline \multicolumn{7}{|l|}{} \\
\hline City centre & 17.9 & 18.4 & 46.6 & 17.0 & 52,000 \\
\hline Inner areas & 17.6 & 27.1 & 32.2 & 23.1 & 301,000 \\
\hline Outer City of Cop., Fr.berg & 19.8 & 21.9 & 36.3 & 22.1 & 273,000 \\
\hline Inner County of Copenhagen & 27.9 & 22.4 & 38.6 & 11.2 & 410,000 \\
\hline Outer County of Copenhagen & 35.7 & 27.7 & 31.5 & 5.0 & 220,000 \\
\hline Inner Counties of Fr.borg \& Rosk. & 36.1 & 27.2 & 31.4 & 5.4 & 164,000 \\
\hline Outer Counties of Fr.borg \& Rosk. & 32.3 & 24.7 & 32.7 & 10.3 & 337,000 \\
\hline
\end{tabular}

\begin{tabular}{|l|r|r|r|r|r|}
\hline City centre & 12.9 & 36.6 & 36.9 & 13.6 & 33,000 \\
\hline Inner areas & 15.3 & 37.9 & 29.2 & 17.6 & 275,000 \\
\hline Outer City of Cop., Fr.berg & 16.9 & 27.4 & 33.6 & 22.1 & 245,000 \\
\hline Inner County of Copenhagen & 21.8 & 20.1 & 39.7 & 18.4 & 381,000 \\
\hline Outer County of Copenhagen & 25.9 & 21.4 & 42.5 & 10.2 & 224,000 \\
\hline Inner Counties of Fr.borg \& Rosk. & 26.3 & 19.5 & 44.8 & 9.4 & 194,000 \\
\hline Outer Counties of Fr.borg \& Rosk. & 24.0 & 21.1 & 41.8 & 13.2 & 377,000 \\
\hline
\end{tabular}

\begin{tabular}{|l|r|r|r|r|r|}
\hline City centre & 13.8 & 35.7 & 39.7 & 10.8 & 36,000 \\
\hline Inner areas & 16.7 & 40.4 & 31.4 & 11.4 & 293,000 \\
\hline Outer City of Cop., Fr.berg & 19.0 & 28.3 & 36.7 & 16.0 & 260,000 \\
\hline Inner County of Copenhagen & 23.4 & 17.4 & 41.5 & 17.6 & 389,000 \\
\hline Outer County of Copenhagen & 25.9 & 17.4 & 44.1 & 12.6 & 228,000 \\
\hline Inner Counties of Fr.borg \& Rosk. & 26.7 & 15.1 & 46.3 & 11.9 & 203,000 \\
\hline Outer Counties of Fr.borg \& Rosk. & 24.8 & 16.9 & 44.5 & 13.8 & 402,000 \\
\hline
\end{tabular}

These two groups do not explain the changes in the distribution of population that have occurred in recent years.

The 20-34 group is nourished by net immigration from the rest of the country. Up to 1976, the share of young people in the total population did not vary much geographically, though a slight over-representation could be observed in the suburbs where persons aged 30-34 already settled. However, from the 1980s the 20-34 group has grown in the Copenhagen region, compared to the country as a whole. This is due to the rapid increase of stu- 
dents following university and similar education, from 115,000 in 1985 to 170,000 in 1998 in Denmark and more than half of them in Copenhagen (Illeris, 2000). The students have progressively invaded the city centre and the inner areas. They have acquired the old, relatively cheap dwellings here, filling the gaps after the decreasing old population (to be mentioned later). Here they find most of the institutions of higher education. But also those studying at Denmark's Technical University and Roskilde University, situated less centrally, tend to live in the City of Copenhagen. Thus in 1999, out of a total of 6484 students at Roskilde University, $66 \%$ lived in the City of Copenhagen and Frederiksberg $(41 \%$ in the inner areas alone), $7 \%$ in Roskilde, and $27 \%$ in the rest of the region or outside it (data from the university administration). The supply of small dwellings and the urban life-style undoubtedly attract them. On the other hand, they have progressively left the sub- and periurban counties - students do not live in their parents' homes any longer. And the supply of subsidized social housing in some of the suburban communes clearly does not attract them.

Figure 2:Persons aged 20-34, percent of total population 2000 (regional mean: 23,9)

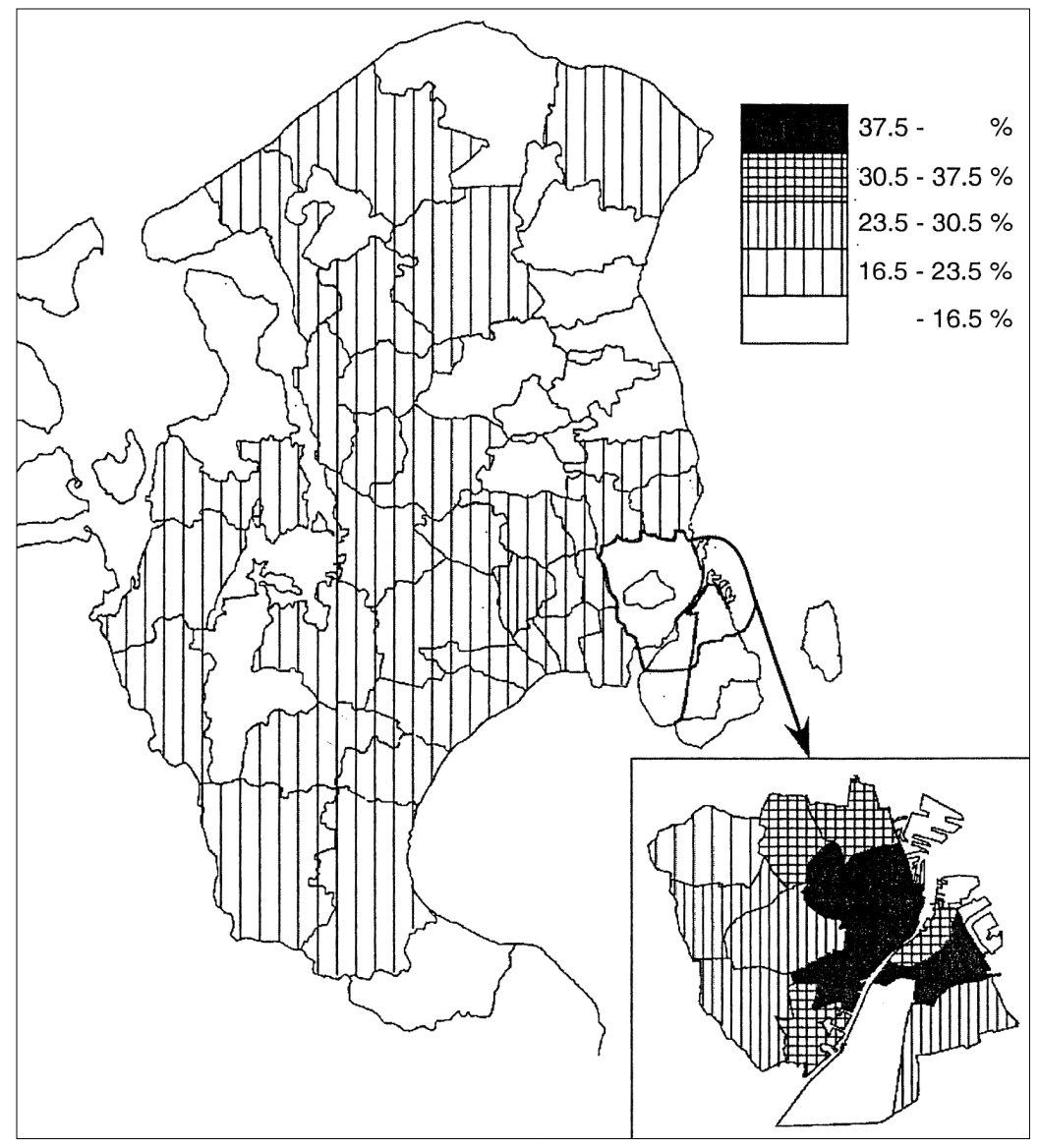


Figure 2 shows the 2000 distribution of the age group 20-34 in more detail. The concentric pattern is very clear, and the highest share - 51\% - is reached in the old archetypical working-class area of Vesterbro.

The net immigration of students is largely responsible for the stabilisation of population in the inner areas, and the net out-migration for stagnation of the suburban population. However, while they often remain in the inner areas for a few years after having finished their education and get their first child there, they tend to leave these areas when they are in their early or mid-30s, together with their children, in favour of the suburbs or other parts of the country. A good deal of them settle in the neighbour regions (counties of West Zealand and Storstrøm) where dwellings are cheaper, and commute to the Copenhagen region (Christoffersen, 2003).

Figure 3: Persons aged 65 or more, percent of total population 1985 (regional mean: 15,3)

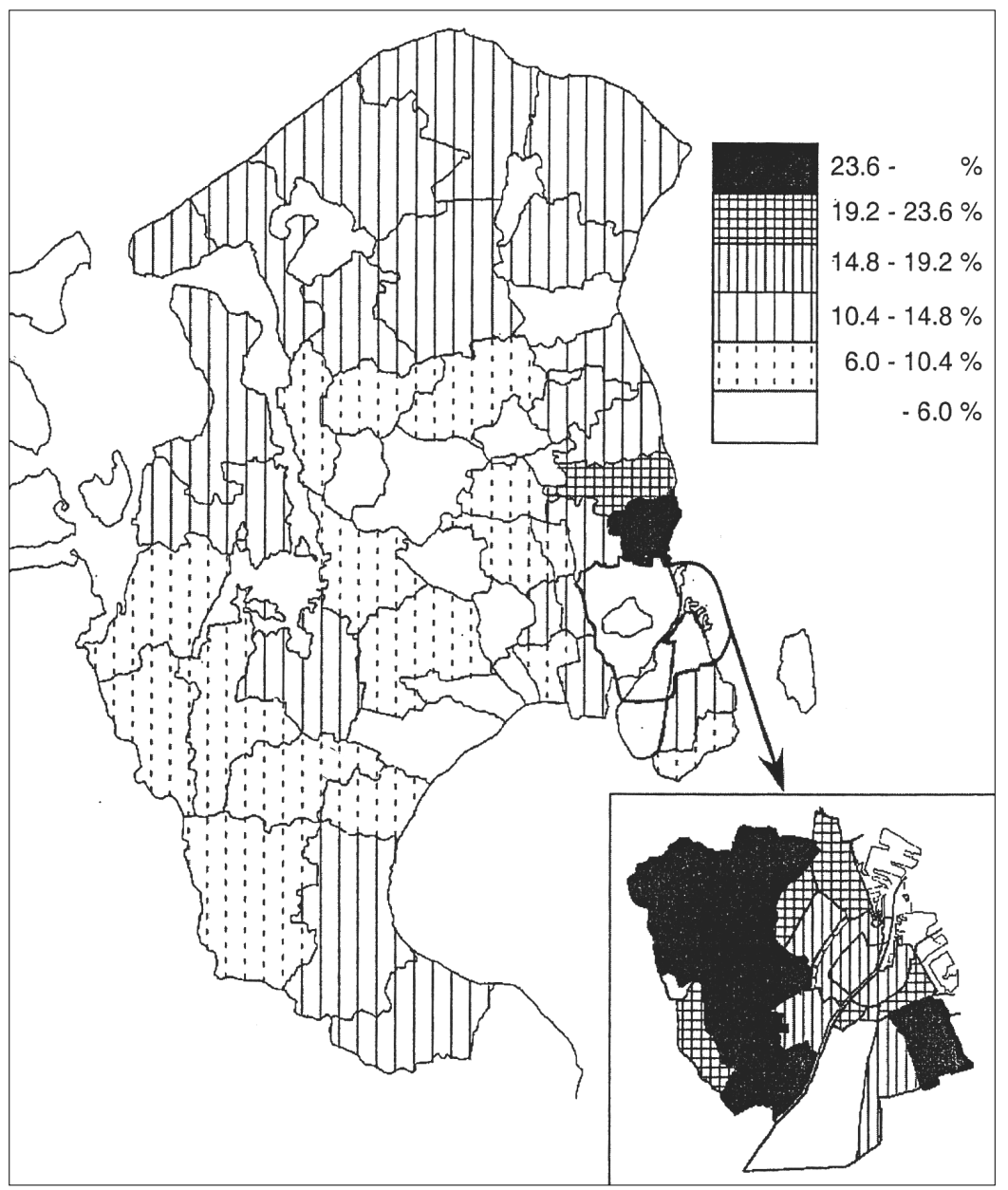


The increasing group of persons aged 65 or more also displays dramatically changing distributions. In 1960, their share was above average in the inner areas surrounding the city centre, while they were under-represented in the rapidly growing suburban zones - corresponding to the traditional urban growth model. Inthe following decades, these geographical differences became more and more pronounced - in some suburban communes their share was less than $3 \%$, while in some central city districts it could reach $38 \%$ of the total population, see figure 3 .

However, in 1994 and especially in 2002, the situation has changed fundamentally. In the central communes, the share of elderly people has diminished radically. Especially the city centre and the inner areas now have less than half the number of persons over 65 they had in 1976. On the other hand, the three outer zones have doubled their number. So on the whole, the elderly are now rather evenly distributed over the concentric zones. What has happened is that that many of the old people in the City of Copenhagen and Frederiksberg have died, and that the next cohort (the successor generation) is small here because many of them migrated to the suburbs in the 1960s and 70s and grow old there.

\section{SOCIO-ECONOMIC GROUPS}

I shall only consider the potentially active age group, while the non-active children and elderly persons already have been covered as the age groups 0-19 and 65 and above. Three main categories may be distinguished:

- The economically active, with paid work.

- The housewives, who were numerous in 1960 (16\% of the total population of the Copenhagen region), but rapidly disappearing as married women took jobs; after 1976 no statistical data are available, and I shall not consider this group.

- The rest who will be called the excluded, until 1994 defined as the age-group 20-64 minus the economically active, from 1994 as as the 20-59 group minus the economically active (which results in an under-estimation).

In the Danish labour market and its regulation, there is traditionally a sharp distinction between

- Independent proprietors and assisting spouses.

- Salary-earners, whose work is usually non-manual ("white collar"), who are paid by the month, and who can only be fired at long notice.

- Wage-earners in a narrow sense, whose work usually is manual ("blue collar"), who are paid by the hour, and who can be fired at short notice.

In the study period only the development from 1976 to 1994 can be shown with reasonable comparability.

Table 2 shows that the share of independent proprietors and assisting spouses peaks in the city centre (a gentrification phenomenon) and in the periurban zones. Their number has decreased in almost all sub-periods and geographical zones. 
Table 2: Socio-economic structure in concentric zones, 1976-1994-2002

\begin{tabular}{|c|c|c|c|c|c|c|c|}
\hline \multirow[t]{2}{*}{$\overline{\text { Percent }}$} & \multicolumn{2}{|c|}{----Economically } & \multicolumn{2}{|c|}{ active---- -------------- } & \multicolumn{2}{|c|}{ Excluded } & \multirow{2}{*}{$\begin{array}{r}\text { Total } \\
\text { (incl. 0-19 } \\
\& \text { 60-) }\end{array}$} \\
\hline & $\begin{array}{l}\text { ident } \\
\text { spou. }\end{array}$ & $\begin{array}{r}\text { Salary } \\
\text { earners }\end{array}$ & $\begin{array}{c}\text { Manual } \\
\text { workers }\end{array}$ & $\begin{array}{r}\text { not } \\
\text { classified } \\
\end{array}$ & $\begin{array}{r}\text { age } \\
20-64 \\
\end{array}$ & $\begin{array}{r}\text { age } \\
-59 \\
\end{array}$ & \\
\hline$\overline{\text { City centre }}$ & 5.7 & 24.2 & 12.8 & 9.7 & 12.8 & & 52,000 \\
\hline Inner areas & 3.4 & 18.9 & 18.1 & 7.9 & 11.1 & & 301,000 \\
\hline Outer City of Cop., Fr.berg & 4.7 & 22.9 & 14.8 & 7.8 & 8.0 & & 273,000 \\
\hline Inner Co. of Copenhagen & 5.3 & 25.5 & 13.8 & 9.4 & 6.9 & & 410,000 \\
\hline Outer Co. of Copenhagen & 4.8 & 26.7 & 13.6 & 8.0 & 6.2 & & 220,000 \\
\hline Inner Co.s of Fr.borg \& Rosk. & 6.2 & 27.9 & 10.6 & 7.0 & 6.9 & & 164,000 \\
\hline Outer Co.s of Fr.borg \& Rosk. & 6.9 & 19.8 & 15.3 & 8.2 & 7.0 & & 337,000 \\
\hline$\overline{\text { City centre }}$ & 5.2 & 32.3 & 7.8 & 8.8 & 19.5 & 16.5 & 33,000 \\
\hline Inner areas & 2.6 & 23.6 & 11.8 & 7.0 & 22.1 & 19.0 & 275,000 \\
\hline Outer City of Cop., Fr.berg & 3.0 & 27.6 & 10.9 & 5.6 & 14.0 & 10.0 & 245,000 \\
\hline Inner Co. of Copenhagen & 3.6 & 28.9 & 11.6 & 5.3 & 10.4 & 5.0 & 381,000 \\
\hline Outer Co. of Copenhagen & 3.6 & 31.3 & 13.2 & 5.5 & 10.3 & 5.7 & 224,000 \\
\hline Inner Co.s of Fr.borg \& Rosk. & 4.6 & 34.8 & 11.5 & 6.3 & 7.1 & 2.9 & 194,000 \\
\hline Outer Co.s of Fr.borg \& Rosk. & 4.7 & 28.0 & 14.8 & 5.7 & 9.7 & 5.1 & 377,000 \\
\hline$\overline{\text { City centre }}$ & & & 60.1 & & & 10.9 & 36,000 \\
\hline Inner areas & & & 54.6 & & & 14.1 & 301,000 \\
\hline Outer City of Cop., Fr.berg & & & 52.1 & & & 8.7 & 252,000 \\
\hline Inner Co. of Copenhagen & & & 51.0 & & & 2.9 & 389,000 \\
\hline Outer Co. of Copenhagen & & & 54.1 & & & 1.4 & 228,000 \\
\hline Inner Co.s of Fr.borg \& Rosk. & & & 55.7 & & & -0.1 & 203,000 \\
\hline Outer Co.s of Fr.borg \& Rosk. & & & 54.0 & & & 1.7 & 402,000 \\
\hline
\end{tabular}

The share of salary earners is high in all zones - in $199425-35 \%$ of the total population especially in the city centre and the suburban zones. It is increasing everywhere. This group will not be studied in more detail.

In 1976, the manual workers were numerous in the inner areas (the traditional working class areas). Soon after, however, this over-representation had vanished, and manual workers now peaked in the periurban zone. The smallest share was found in the city centre. In general, the share of manual workers has declined in the region as in most of Western Europe (a tendency which the data probably under-estimate). The stabilisation of the inner area population may partly be interpreted as a sign that this process is approaching its end.

Figure 4 shows the 1999 distribution of clerks, service and sales workers, skilled workers and operators, according to the International Standard Classification of Occupations. The geographical distribution is dominated by manual workers, though the data include a good deal of salary earners. There is still an above-average representation in the southern and western inner areas, but especially in the western suburbs and in the whole periurban fringe (including the old mill town of Frederiksværk in the northwestrern corner of the region, which has little to do with Copenhagen). On the other hand, the northern suburbs have very few manual workers. The pattern of variation is radiating rather than concentric. 
Figure 4: Clerks, service and sales workers, skilled workers, operators and workers with unknown occupation, percent of population, 1999 (Regional mean: 30,3\%)

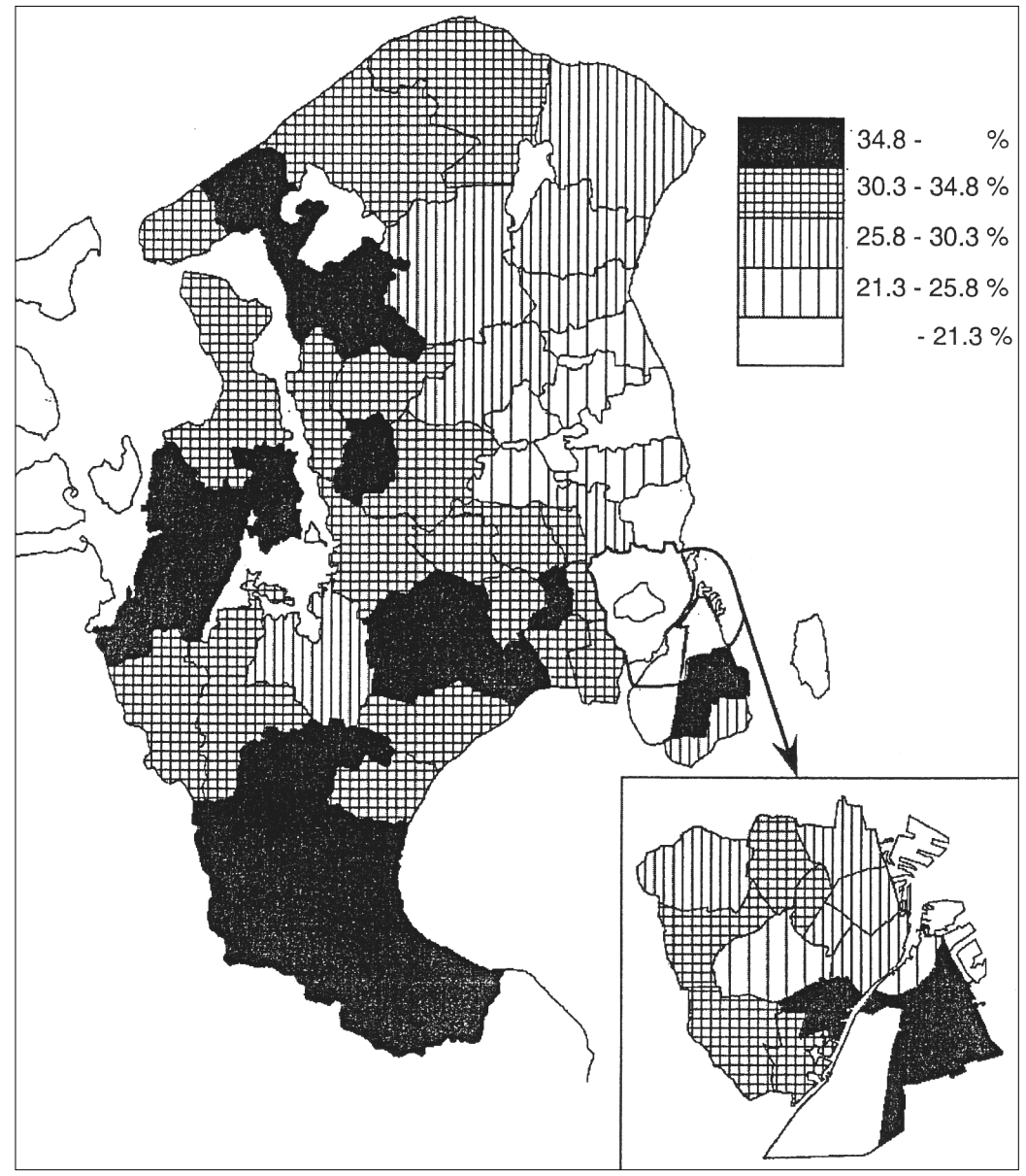

The distribution of excluded persons is highlighted by tables 6-9. In 1976, it must be taken into account that some housewives are still included in the data. It is safe to say that the share of truly excluded peaked in the inner areas.

While in 1979, when the current series of official unemployment data were created, $4.9 \%$ of the region's labour force was unemployed, this share increased to 7,5\% in 1985 and $11.7 \%$ in 1994 . In a parallel way, the number of truly excluded persons, as here defined, grew. The concentration of excluded persons in the inner areas and the city centre became more and more pronounced, while it remained low in the suburban zones. In Illeris (1984), it is shown that the above-average unemployment in the central communes is due to men in the 25-49 age bracket, many of whom are divorced, are immigrants, show high sickness rates or have other social problems, and who were attracted by the old, cheap dwellings in this area. 
Thus the traditional working-class areas had not only turned into areas of retired people, as already mentioned. They had also turned into areas of excluded persons.

Figure 5: Excluded persons 1.1.1994 (persons aged 20-64 minus employed persons, as percent of total population) (regional mean: 12,5\%)

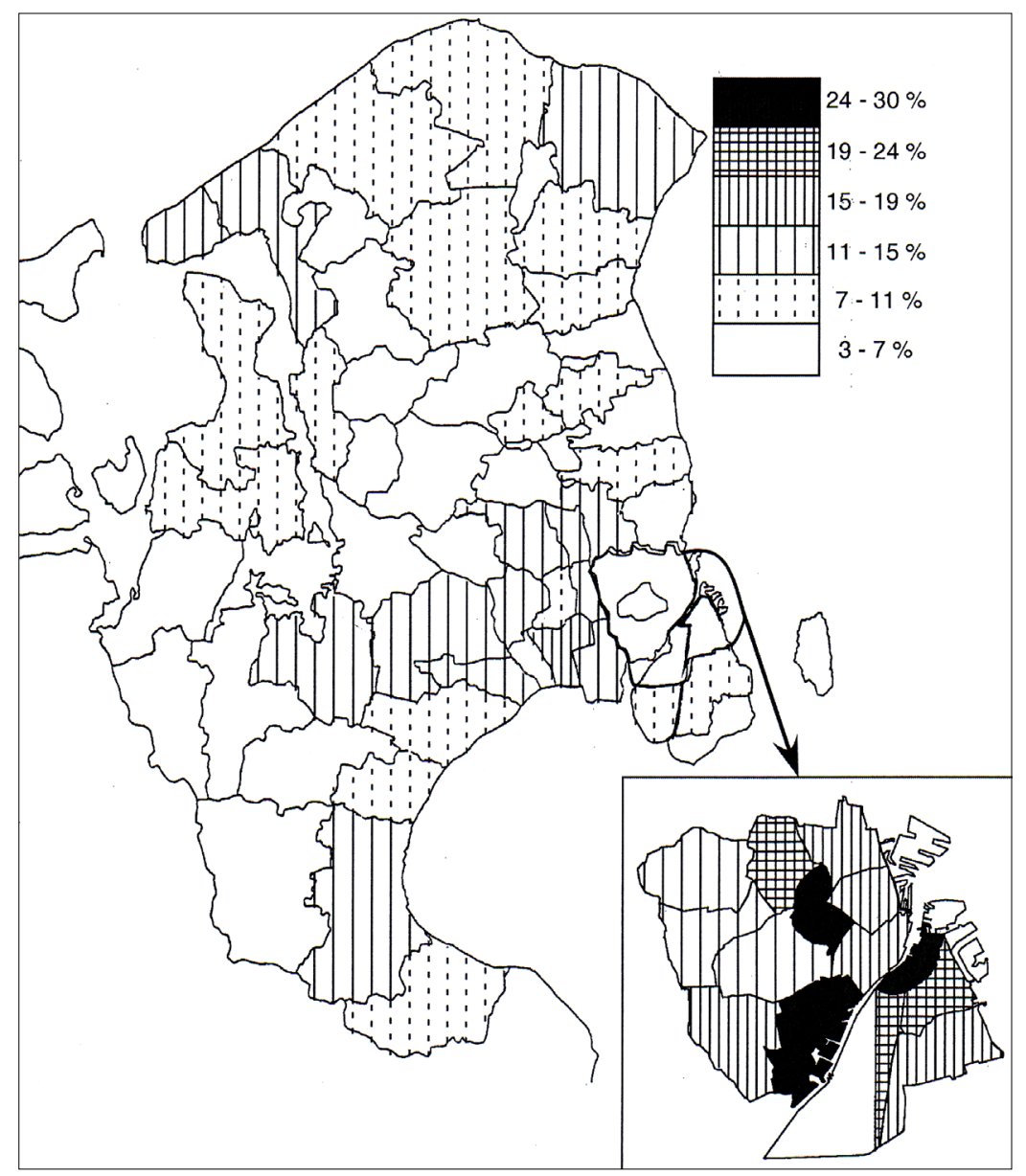

Figure 5 highlights the share of excluded persons in 1994. In some inner area districts, it amounts to $24-30 \%$ of the total population, corresponding to $35-40 \%$ of the population in the 20-64 age bracket. This concentration is connected with the supply of old, cheap dwellings in the inner areas, but the chains of causality are undoubtedly complicated in such areas of sub-cultures of exclusion. In the suburbs, the geographical variation is rather between radiating sectors than between concentric zones, being clearly higher to the west than to the north. This has much to do with the differences in the supply of subsidized social housing. 
From 1994 to 2002, the share of excluded persons has decreased (as has the official rate of unemployment, from $11.7 \%$ to $4.5 \%$ of the region's labour force). In the suburbs, it has become very low. But there are still differences between the radiating sectors, with a higher share of excluded persons to the west than to the north. In the central municipalities, the number of excluded persons is still considerable, especially in the inner areas.

It could be claimed that the students have crowded out from the inner areas some of the excluded persons with fewer resources. Some of them seem to have moved to cheaper rural dwellings to be found outside the Copenhagen region, in the regions of West Zealand and Storstrøm.

\section{ETHNIC GROUPS}

Until the late 1960s, the population of the Copenhagen region was ethnically very homogeneous. However, around 1970 - when workers were scarce - a modest number of "guest workers" were invited. They came especially from the then Yugoslavia, Turkey and Pakistan. The doors were soon closed again, except for Nordic and EU immigrants. But family reunification and refugees from various parts of the world plus their children have ever since contributed to an increasing number of aliens. At the same time, the general internationalisation has meant a steadily growing exchange of migrants between the EU countries and the Nordic countries.

Table 3: Citizenship in concentric zones, 1978-1994-2002

\begin{tabular}{lrrrr}
\hline Percent & Danish & $\begin{array}{c}\text { Other EU, Nordic, Other European, Asian, } \\
\text { American, Oceanic }\end{array}$ & Totrican, stateless, n.a. \\
\hline City centre & 92.3 & 4.7 & 3.0 & 49,000 \\
Inner areas & 94.2 & 2.2 & 3.6 & 288,000 \\
Outer City of Cop., Fr.berg & 97.1 & 1.6 & 1.3 & 265,000 \\
Inner County of Copenhagen & 97.4 & 1.6 & 1.0 & 406,000 \\
Outer County of Copenhagen & 95.9 & 1.9 & 2.2 & 225,000 \\
Inner Co.s of Fr.borg \& Rosk. & 97.1 & 2.0 & 0.9 & 175,000 \\
Outer Co.s of Fr.borg \& Rosk. & 97.6 & 1.2 & 1.2 & 344,000 \\
& & & 3.0 & \\
\hline City centre & 89.8 & 7.2 & 6.9 & 261,000 \\
Inner areas & 90.0 & 3.1 & 4.0 & 249,000 \\
Outer City of Cop., Fr.berg & 93.6 & 2.4 & 3.1 & 381,000 \\
Inner County of Copenhagen & 95.2 & 1.7 & 5.4 & 224,000 \\
Outer County of Copenhagen & 92.9 & 1.7 & 3.1 & 194,000 \\
Inner Co.s of Fr.borg \& Rosk. & 95.3 & 1.7 & 2.7 & 377,000 \\
Outer Co.s of Fr.borg \& Rosk. & 96.1 & 1.2 & & 2.2 \\
& & & 7.7 & 301,000 \\
\hline City centre & 90.5 & 7.3 & 6.0 & 252,000 \\
Inner areas & 87.7 & 4.6 & 4.3 & 389,000 \\
Outer City of Cop., Fr.berg & 90.9 & 3.0 & 5.6 & 228,000 \\
Inner County of Copenhagen & 93.7 & 2.1 & 3.5 & 203,000 \\
Outer County of Copenhagen & 92.6 & 1.9 & 2.8 & 402,000 \\
Inner Co.s of Fr.borg \& Rosk. & 94.8 & 1.7 & & \\
Outer Co.s of Fr.borg \& Rosk. & 95.8 & 1.4 & & \\
\hline
\end{tabular}


Statistical data are only available from 1978. The need for statistical time-series ma-kes it necessary to use the criterion of citizenship, not including a good deal of immigrants who have obtained Danish citizenship.

Table 3 shows the steady increase in the number of foreign citizens; they have contributed decisively to the stabilisation of the region's population.

The group of other European, Asia and African citizens and stateless persons constitutes an important share of the population of the City of Copenhagen - especially the inner areas - and in the suburban zones (especially the outer belt of the County of Copenhagen). Their distribution in 2000 is shown in figure 6.

Figure 6: Citizens of Asian and African countries and European except EU and Nordic countries, plus stateless persons, 2000. (regional mean: 5,2\%)

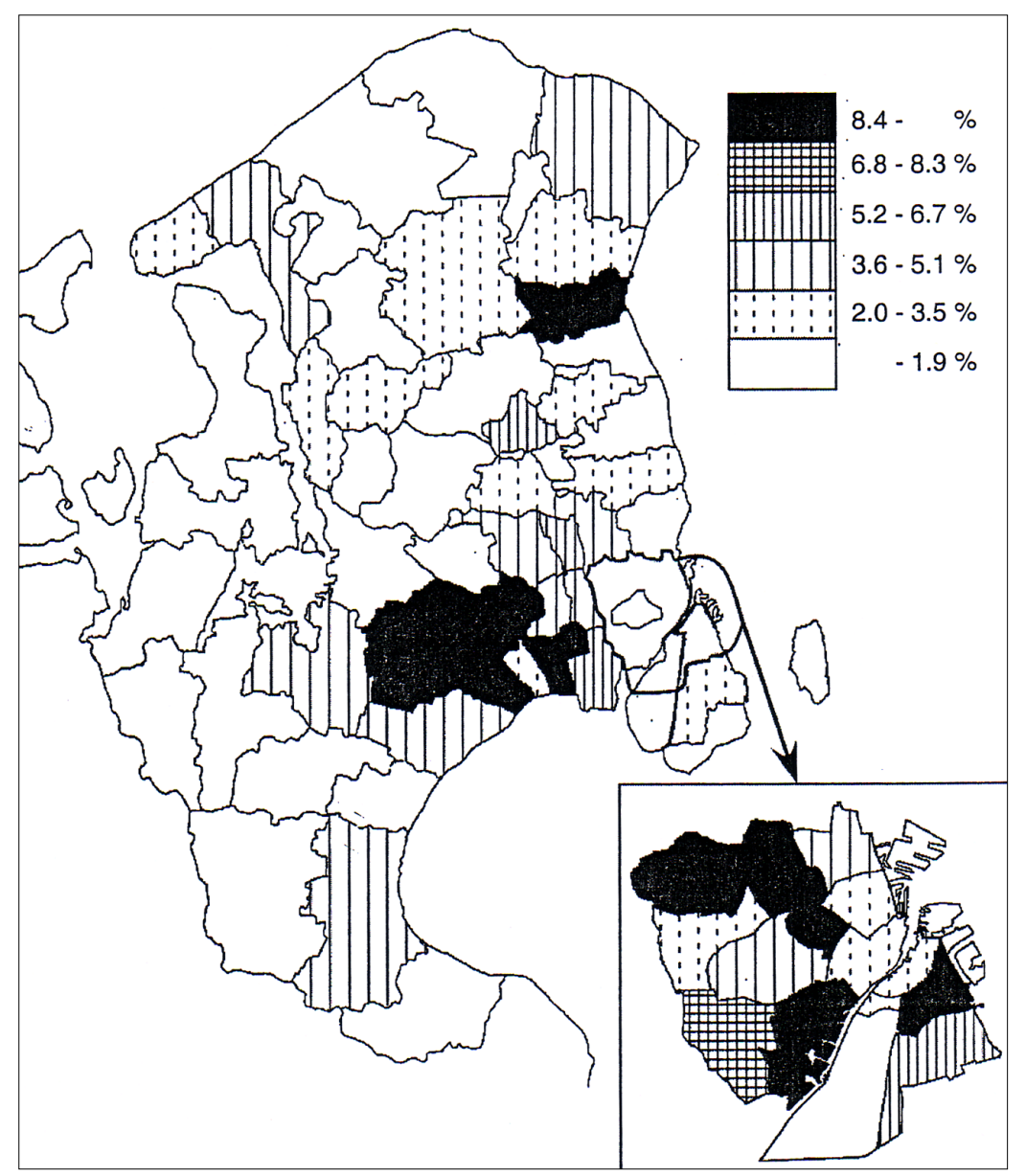

The variation in the share of citizens from poor countries is rather according to radiating sectors than by concentric zones: They concentrate in the western rather than in the nort- 
hern sectors (with a few exceptions). This pattern has much to do with the housing supply: They find cheap dwellings in the inner areas and in subsidized social housing in the western suburban communes, which have the power to and often do reserve a number of social housing flats to immigrants. The pattern seems to be reinforced by a wish to live close to other immigrants from the same country (Andersen, Andersen \& Ærø 2000). However, there are hardly ethnic concentrations that exclude people from other countries. - On the other hand, wealthy communes with little social housing and rural communes have few immigrants from poor countries.

Immigrants from poor countries have in particular contributed to the stabilisation and later to the renewed growth of the population of the City of Copenhagen.

EU, Nordic and American citizens have a different distribution with a relatively high share of the city centre population, but also above average in some inner area districts and some wealthy, northern suburbs. In most sub- and periurban communes they are very few. This pattern shows that this type of internationalisation is primarily nourished by resourceful people.

\section{CONCLUSIONS}

The modest city of Copenhagen of the mid-19th century developed through rapid population growth to the populous region of Copenhagen of the 1970s. It then entered a period of stagnation, but from the early1990s the population has resumed its growth. Up to the 1970s, the growth was accompanied by an outward expansion where people migrated to new dwellings at the periphery, while the central communes suffered heavy population losses in the $1950 \mathrm{~s}$ and $60 \mathrm{~s}$. In the $1970 \mathrm{~s}$ and $80 \mathrm{~s}$, the decrease in the central communes flattened out, but spread to the inner suburbs, while the growth rates in the outer suburbs decelerated. The growth wave gradually came to a standstill. In the 1990s, the resumed growth took place at a surprisingly equal rate all over the urban region (and even in parts of the neighbour regions).

Analyses of the concentric distribution of the age, socio-economic and ethnic population groups have shown that up to the 1970s, the inner areas had an over-representation of mid-age and elderly persons and of manual workers, while the suburbs had many children and young persons and many salary earners.

From the 1980s, this pattern changed: In the central communes, the numbers of manual workers declined, while that of young persons, excluded persons, immigrants from poor countries and especially of elderly persons increased - while in the suburbs mid-aged people and children became very dominant.

The 1990s witnessed a second change: The city centre became the reserved place of living for independents, salary earners and immigrants from rich countries. At the same time, the surrounding inner areas lost large shares of their elderly population. They were substituted by students and persons who had just finished their education. Inner suburbs got a large share of elderly people, while outer suburbs remained dominated by mid-age groups and children, with very few in the 20-34 age bracket. 
This means that the best known theories of urban structure, such as those suggested by Burgess, Alonso and Harvey, are not very useful in understanding what has happened in recent decades in the Copenhagen region. They had not foreseen that the growth wave could come to a geographical standstill, accompanied by densities increasing at equal rates all over the urban region. The mechanisms causing this phenomenon have not been studied in depth. However, as a hypothesis it could be due to the policies of local governments, trying to stabilize their financial situation by modest, but steady growth. (The influence of local governments on the housing market and the physical development was of course much weaker in the societies in which these theorists have worked).

Second, the fact that the socio-economic pattern primarily is radiating rather than concentric rather conforms to the results of many social area studies than to the abovementioned theorists who all took it for given that the wealthy would occupy the outer and the poor the inner areas. To understand the radiating pattern, it must be borne in mind that in Denmark since World War II, local governments have had powers to influence the market of rented dwellings substantially, in particular to promote or to omit promoting subsidized social housing. This has created a dichotomy between right-leaning local governments (in the Copenhagen region mainly to the north) with few cheap dwellings and left-leaning local governments (the City of Copenhagen and most western suburbs) with many cheap dwellings. To this must be added the old stock of flats in the City of Copenhagen where legislation has kept prices low (though urban renewal and possibilities of converting rented flats to occupier ownership have changed the picture somewhat).

On the other hand, the concentric structure is important as regards the age composition in the Copenhagen region - as found by social area studies in many other places. However, the traditional wave-pattern of preponderance of elderly people in the old, central zones and young people in the new, peripheral zones has broken down. It was undermined by the extremely rapid suburbanisation of the 1960s and 70s which pulled a whole generation out of the central communes, leaving mainly an elderly population. When from the 1980s these people died without having a successor cohort of their own type, the decline in population did not continue, because the empty dwellings were taken up, first by a large number of excluded persons in this period of unemployment, second by international immigrants, third - and in the 1990s predominantly - by the rapidly growing number of students who were less poor than earlier generations of students and much less inclined to remain in their parents' -primarily suburban - homes.

As regards the gentrification theories, they may have some relevance for what has happened in the city centre of Copenhagen. In the inner areas - the 19th century and early 20th century working class areas on which this paper has focussed - there has not been much gentrification, understood as invasion of upper middle classes, though it can be found here and there. The invasion by students is a different phenomenon, they are culturally but usually not financially resourceful (though in some cases their parents buy flats for them). And most of them settle there only for a limited period of their lives. It is necessary to take more factors into account in our theories - it is significant that Hamnett only in one sentence mentions that gentrifiers often are singles or childless couples. We need to recognize that the needs and demands of different household types, including parents with children, students and retired people, are different. 
To what extent similar observations can be made in other city regions and may form the basis of further general theory-building remains to be seen.

\section{References}

Alonso, W., 1960: A Theory of the Urban Land Market. Papers and Proceedings of the Regional Science Association, VI, 149-157.

Andersen, H.S., Andersen, H.T. \& Ærø, T., 2000: Social polarisation in a segmented hou Statistical data are only available from 1978. The need for statistical time-series makes it necessary to use the criterion of citizenship, not including a good deal of immigrants who have obtained Danish citizenship.sing market: Social segregation in Greater Copenhagen. Geografisk Tidsskrift, 100, 71-83.

Burgess, E.W., 1925: The Growth of the City: An Introduction to a Research Project. 47-62 in Park, R.E., Burgess, E.W. \& McKenzie, R.D. (eds), The City. Chicago: University of Chicago Press.

Christoffersen, H., 2003: De regionale mønstre i boligforbruget. København: AKF Forlaget.

Hamnett, C., 1991: The Blind Men and the Elephant: the Explanation of Gentrification. Transactions of the British Institute of Geographers. NS 16, 173-189.

Harvey, D., 1989: The Urban Experience. Oxford: Blackwell.

Illeris, S., 1984: Arbejdsløshed og arbejdsmarkeder i Hovedstadsregionen. København: Amternes og Kommunernes Forskningsinstitut.

Illeris, S., 1994: Why was the Central City Population Stabilized? The Case of Copenhagen. 595-608 in Braun, G.O. (ed), Managing and Marketing of Urban Development and Urban Life. Abhandlungen 52, Institut für Geographische Wissenschaften, Freie Universität Berlin. Berlin: Dietrich Reimer.

Illeris, S., 2000: Hvorfor vokser København igen? Byplan, 52, 3, 98-103.

Pedersen, P.O., 1967: Modeller for befolkningsstruktur og befolkningsudvikling i storbyområder - specielt med henblik på Storkøbenhavn. København: Statens Byggeforskningsinstitut.

Simonsen, K., 1976: Segregationsprocessen i mindre danske købstæder. København: Geografisk Centralinstitut, Københavns Universitet. 